\title{
Adaptation of Intercultural Sensitivity Scale for Turkish Medical Students
}

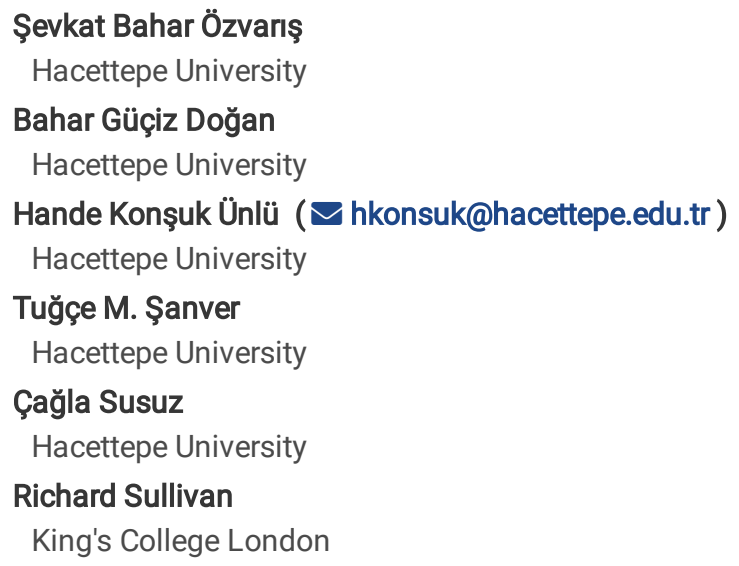

\section{Research Article}

Keywords: intercultural sensitivity, scale, medical education, reliability-validity, confirmatory factor analysis, Cronbach's alpha

Posted Date: February 26th, 2021

DOI: https://doi.org/10.21203/rs.3.rs-225741/v1

License: @) (i) This work is licensed under a Creative Commons Attribution 4.0 International License. Read Full License 


\section{Abstract}

Background: Different languages and insufficient levels of intercultural sensitivity among healthcare providers hinder migrants from benefiting from health services, resulting in a lack of trust in service providers and non-adherence to the treatment. This study aims to verify the validity and reliability of the "Intercultural Sensitivity Scale" developed by Chen and Starosta among Turkish medical students. Methods: Data were collected between December 18, 2017, and February 28, 2018, from 667 students. In order to demonstrate the construct validity of the scale, the data were randomly divided into two parts using the functions in the SPSS package program. For the first half of the data ( $\mathrm{n} 1=337)$, exploratory factor analysis (EFA) based on polychoric correlation was applied together with the oblique rotation method. For the second half of the data (n2=330), confirmatory factor analysis (CFA) based on polychoric correlations was applied to confirm the factor structure of the scale. In order to demonstrate the reliability of the scale, the Cronbach's alpha reliability coefficient, which shows internal consistency, and Spearman-Brown coefficients, which shows the two-half reliability, were calculated. Results: Of the participants, $52.6 \%$ were female and the mean age was 24.2 \pm 1.4 . Only one-third of the students stated they had knowledge about intercultural sensitivity. Cronbach's alpha coefficient for the scale was 0.906. The Spearman-Brown coefficients for the whole scale and its sub-dimensions show that reliability values were also sufficient. In the confirmatory factor analysis, fit indices (RMSEA: 0.077, GFI: 0.98, CFI: 1.00) demonstrated a very good model fit. Conclusions: These results confirmed that the scale consisting of 23-items and 5-dimensions is a valid and reliable tool and can be used for Grade V and VI Turkish medical students. It is considered that integrating intercultural sensitivity training in undergraduate education of physicians would help to increase the number of physicians who are sensitive to different cultures and thus contribute to reducing disparities in healthcare provision. Keywords: intercultural sensitivity, scale, medical education, reliability-validity, confirmatory factor analysis, Cronbach's alpha

\section{Introduction}

One of the most important political, economic and social changes brought along by globalization has been migration across national boundaries. Turkey is geographically positioned at the junction of the continents of Asia and Europe, covering some 783 thousand km² and is a transit country for migration movements between countries on these two continents [1]. Turkey is located between Asia and Europe like a bridge. Depending on this situation, throughout history, many people living in the countries located in the east and south of Turkey have emigrated to Turkey or accommodated for a while to migrate to the west of the country. In 2011, there began a conflict in Syria and a great amount of people had moved to Turkey. As of November 2020, the number of immigrants reached approximately 5 million. Among these people, 3.6 million are Syrian refugees (1.8\% are living in camps) according to the Directorate General of Migration Management (DGMM) and United Nations High Commissioner for Refugees (UNHCR) [2, 3]. Most of them are residing in urban cities [4], and have been privileged protection. Besides Syrian refugees, there are asylum seekers (nearly 330,000) and refugees from other countries eastern countries [5]. Some of these immigrants (that counts almost 1.1 million) have residency permit for various purposes [6], and some 450,000 are undocumented migrants [7].

At the beginning of the big migration wave from Syria, the population of the provinces of eastern and South-eastern region of Turkey had affected. Then, with the movement of migrants to the other regions and provinces, almost all Turkish population living together with the people who have different cultural characteristics. The continuing growth, of migrants entering and exiting, and residing in Turkey further exacerbates the harmony problems.

The negative attitude of local residents against the migrants might affect the attitudes of health personnel servicing in the same community as well.

The health personnel consider the migrant patients as additional workload [8]. In some studies, performed on 2016 among health personnel and Syrian refugees, lack of communication, increased workload, problems in obtaining informed consent, invasion of privacy, could not establishing empathy, insufficient management of diagnosis and treatment process were determined as the problems faced while serving the refugees.

On the other hand, the migrants stated the problems they had faced while obtaining health service as lack of trust, fear from health personnel, have no health security, lack of communication and relatedly not being able to give informed consent, and not being able to control privacy [9, $10,11]$. In another study, the main problem that refugees had related to access the health services was stated as the negative attitude of health personnel [12]. Different languages and insufficient levels of intercultural sensitivity among healthcare providers might hinder migrants benefiting from these services, resulting in lack of trust in service providers and often non-adherence to the treatment $[13,14]$.

Recent studies suggest that migrants receive lower-quality service compared with the general population $[15,16]$. Studies also show that the quality of health worker-migrant relationship varies depending on the own beliefs and perceptions of health worker and his/her feelings and attitudes towards migrants [17]. Healthcare workers who could understand the dynamics of other cultures are capable of evaluating the behavioral patterns of people they serve in connection with their cultural background; these behaviors affect the health status of individuals. On the other hand, the failure to develop cultural sensitivity may create barriers between healthcare workers and the people they serve $[18,19]$. 
In order to be able to meet the healthcare needs of mix-communities with different cultures sourced from migration, medical schools need to raise students sensitive to, and familiar with, a broad range of cultural issues. Due to the intensive movements of migration among countries in our region in recent years, medical students are expected to learn about different cultures, as they more commonly encounter patients from different cultures than ever during their clinical practices. Thus, they need be more competent in demonstrating a culture-specific approach compared with other disciplines [14, 19].

The education programs of medical schools should include specific learning and teaching activities for students to develop the skills required to provide non-judgmental and non-discriminatory health services to all. It is important to identify the current state of intercultural sensitivity and observe the development of students in this regard. Thus, a level of intercultural sensitivity must be identified as the first step towards creating greater awareness. Some studies shed light on how to shape undergraduate education of medical students to equip them with the intercultural sensitivity skills $[20,21,22]$.

The only scale whose primary purpose is to measure the emotional aspects of intercultural competence is the Intercultural Sensitivity Scale (ISS). In addition, there is no similar tool in Turkish to assess intercultural competence. From this point, the main objective of this study is to adapt ISS to Turkish. The study aims verifying the validity and reliability of "Intercultural Sensitivity Scale" developed by Chen and Starosta [23] among medical students.

\section{Methods}

\section{Participants and procedure}

Data were collected at the Faculty of Medicine of Hacettepe University, Turkey in the year 2018. Permission from the Dean's Office of the Faculty of Medicine of Hacettepe University, and Hacettepe University Non-Interventional Clinical Researches Ethics Board's approval were obtained as well as participants' informed consents. This study has been conducted with the guidance of ethical approval. A total of 667 Turkish students out of 956 (69.8\%) were participated to the study (404 fifth grade and 263 sixth grade). More than half of the participants (52.6\%) were female, and the mean age was $24.2 \pm 1.4$. Some socio-demographical and educational characteristics, engagement with other cultures were questioned via a pre-tested questionnaire, also.

\section{Instrument}

The "Intercultural Sensitivity Scale" developed by Chen and Starosta (2000) was used in this adaptation procedure. The original scale was first tested with 72 items, then reduced to 44 items at the second stage and was finalized with 24 items. It was decided to use the second draft with twofold number of items (44 items), which is provided in the referred article [23]. Considering the cultural differences between Turkey and the country where the scale was developed, increasing the number of items was meaningful to be validated.

The scale consists of statements scored through a 5-point Likert method: 1 = strongly disagree, 2 =disagree, $3=$ uncertain, $4=$ agree and $5=$ strongly agree. Items 2, 6, 8, 10, 12, 14, 17, 20 and 43 of the scale are reverse scored. The scale score does not have a cut-off point. High scores reflect high intercultural sensitivity [23].

\section{Statistical Analysis}

Data entry and evaluation were conducted through statistical package program IBM SPSS 23.0. The descriptive statistics used in the research were expressed as numbers and percentages; mean, standard deviation, median, $1^{\text {st }}-3^{\text {rd }}$ quartile, minimum-maximum values. The correlations between categorical variables were evaluated through chi-square test, and level of significance was adopted as $p<0.05$. In order to demonstrate the construct validity of the scale, the data were randomly divided into two parts using the functions in the SPSS package program. For the first half of the data $\left(n_{1}=337\right)$, exploratory factor analysis $(E F A)$ based on polychoric correlation was applied together with the oblique rotation method. For the second half of the data $\left(\mathrm{n}_{2}=330\right)$, confirmatory factor analysis (CFA) based on polychoric correlations was applied to confirm the factor structure of the scale. Exploratory factor analysis was conducted using FACTOR 10.8.02 program, while confirmatory factor analysis was conducted using LISREL 8.80 program. In order to demonstrate the reliability of the scale, the Cronbach's alpha reliability coefficient, which shows internal consistency, and Spearman-Brown coefficients, which shows the two-half reliability, were calculated. The difficulty and discrimination coefficients and Cronbach's alpha if item deleted statistics calculated when the item was deleted.

\section{Results}


Of the final group of 667 medical students Only $1 \%$ of the participants' parents was not Turkish. Two-third of respondents have neighbors from different cultures, and $87.7 \%$ stated that they interacted with people from different cultures (Table 1). Of the participants, $79.3 \%$ reported that they spoke at least one foreign language other than Turkish. Within the last year, $64.8 \%$ of students examined patients from different cultures during their clinical practices. Only one-third of the students stated that they had heard the term 'intercultural sensitivity'; $22.9 \%$ had learned from media, $16.8 \%$ from friends/family, and only $8,2 \%$ from university lectures (Table 1 ).

Table 1. Some Characteristics of Participants (Hacettepe Univ.-Turkey, 2018)

\begin{tabular}{|c|c|c|}
\hline Characteristics & $\mathbf{n}$ & $\% 1$ \\
\hline \multicolumn{3}{|c|}{ Neighbor from different cultures $\left(n=658^{2}\right)$} \\
\hline Yes & 433 & 65.8 \\
\hline No & 159 & 24.2 \\
\hline Don't know & 66 & 10.0 \\
\hline \multicolumn{3}{|c|}{ Interaction with people from different cultures $(n=667)$} \\
\hline Yes & 585 & 87.7 \\
\hline No & 82 & 12.3 \\
\hline \multicolumn{3}{|c|}{ Heard the term 'intercultural sensitivity' ( $\left.n=649^{2}\right)$} \\
\hline Yes & 200 & 30.8 \\
\hline No & 449 & 69.2 \\
\hline \multicolumn{3}{|c|}{ Source of knowledge ${ }^{3}$} \\
\hline Media & 153 & 22.9 \\
\hline Family/friends & 112 & 16.8 \\
\hline University lectures & 55 & 8.2 \\
\hline Others ${ }^{4}$ & 16 & 2.1 \\
\hline
\end{tabular}

${ }^{1}$ Column percentages

${ }^{2}$ Various number of non-responses for each variable.

${ }^{3}$ Multiple-choice answers; percentages were calculated separately from total $(n=667)$.

${ }^{4}$ Secondary education, foreign language course, TURKMSIC, IFMSA, social media, AFS Volunteers Association

\section{Adaptation process of the scale}

\section{Language Validity}

At the first stage of the study, items of the original scale were translated into Turkish by the researchers. At the second stage, a Turkish Language and Literature expert evaluated the draft translation with regard to ambiguity. As the third step, the items optimized in Turkish language were translated into English by a native English speaker professor at the American Culture and Literature Department at Hacettepe University. At the last step, the items translated back to English were compared with the original items of the scale before finalizing the Turkish version.

\section{Exploratory Factor Analysis}

For the factor analysis, exploratory and confirmatory analyses were conducted by randomly dividing the dataset into two approximately equal parts. In order to determine whether the items are compatible with the factor structure, exploratory factor analysis (EFA) based on polychoric correlations was applied for the first half of the scale, and oblique rotation method was used. The factor analysis was repeated by excluding 21 
items with factor load smaller than 0.30 which were loaded to multiple dimensions. In the end, final version of the scale consisting of 23 items and 5 dimensions was obtained. In order to determine whether the data and sample are suitable for factor analysis, Kaiser-Meier-Olkin (KMO) test, which shows sampling adequacy, and Bartlett test, which shows sphericity were conducted. KMO value (0.874) shows that the sample size was sufficient for factor analysis. [24]. The result of Bartlett test has been found to be statistically significant, which supports the hypothesis that the correlations between items are different from zero.

The factor loads obtained from EFA, the eigenvalues and the variances explained by eigenvalues are shown in Table 2. As a result of the analysis, a five-dimensional structure with eigenvalues greater than 1 has been obtained; these eigenvalues explain $70.4 \%$ of the total variance. These five dimensions were as follows: Interaction Confidence, Interaction Awareness, Respect of Cultural Difference, Difficulty in Interaction and Interaction Enjoyment.

Table 2. Factor loadings, eigenvalues and the variance explained by eigenvalues 


\begin{tabular}{|c|c|c|c|c|c|}
\hline Factor Loadings & & & & & \\
\hline Items & $\begin{array}{l}\text { Interaction } \\
\text { Confidence }\end{array}$ & $\begin{array}{l}\text { Interaction } \\
\text { Awareness }\end{array}$ & $\begin{array}{l}\text { Respect of Cultural } \\
\text { Difference }\end{array}$ & $\begin{array}{l}\text { Difficulty in } \\
\text { Interaction }\end{array}$ & $\begin{array}{l}\text { Interaction } \\
\text { Enjoyment }\end{array}$ \\
\hline Item 1 & 0.658 & & & & \\
\hline Item 2 & 0.499 & & & & \\
\hline Item 3 & 0.742 & & & & \\
\hline Item 4 & 0.838 & & & & \\
\hline Item 24 & 0.631 & & & & \\
\hline Item 11 & 0.872 & & & & \\
\hline Item 13 & 0.796 & & & & \\
\hline Item 15 & & 0.599 & & & \\
\hline Item 17 & 0.571 & & & & \\
\hline Item 18 & 0.888 & & & & \\
\hline Item 19 & 0.924 & & & & \\
\hline Item 20 & & & 0.749 & & \\
\hline Item 22 & 0.547 & & & & \\
\hline Item 23 & 0.641 & & & & \\
\hline Item 25 & 0.582 & & & & \\
\hline Item 30 & 0.610 & & & & \\
\hline Item 36 & 0.599 & & & & \\
\hline Item 38 & & & & 0.602 & \\
\hline Item 26 & 0.662 & & & & \\
\hline Item 33 & 0.537 & & & & \\
\hline Item 40 & 0.728 & & & & \\
\hline Item 41 & 0.771 & & & & \\
\hline Item 42 & & & & & 0.861 \\
\hline & Eigenvalues & $\begin{array}{l}\text { Total variance } \\
\text { explained }\end{array}$ & $\begin{array}{l}\text { Cumulative variance } \\
\text { explained }\end{array}$ & & \\
\hline Interaction Awareness & 8.448 & $36.7 \%$ & $36.7 \%$ & & \\
\hline Difficulty in Interaction & 3.045 & $13.2 \%$ & $49.9 \%$ & & \\
\hline Respect of Cultural Difference & 1.759 & $7.7 \%$ & $57.6 \%$ & & \\
\hline Interaction Enjoyment & 1.736 & $7.6 \%$ & $65.2 \%$ & & \\
\hline Interaction Confidence & 1.197 & $5.2 \%$ & $70.4 \%$ & & \\
\hline $\begin{array}{l}\text { KMO }=0.874 ; \text { Bartlett statistics }= \\
3515.9(p<0.00001)\end{array}$ & & & & & \\
\hline
\end{tabular}

\section{Confirmatory Factor Analysis}

In order to confirm the factor structure of the scale (23 items and 5 dimensions), confirmatory factor analysis (CFA) based on polychoric correlations was applied to the second half of the data, which was randomly divided into two parts. Factor loadings were found between 0.53 and 0.83. In Figure 1, the path diagram shows the path coefficients obtained from CFA analysis. In the confirmatory factor analysis, the fit indices were obtained to assess the fitness of the model constructed in the analysis. The (chi-square/degree of freedom) value was found as 2.96, which demonstrated a good model fit (i.e. between 1-3). The RMSEA (Root Mean Square of Error Approximation) fit index value was 
0.077 , reflecting a good fitness $(<0.08)$. The Goodness of Fit Index (GFI) was found as 0.98 , which shows that the model has a very good degree of fitness (>0.95 =very good). Other fit index values were as follows: NFI (Normed Fit Index) $=1.00$ ( $>0.95$ very good), CFI (Comparative Fit Index) $=1.00$ (>0.95 very good) and RMR (Root Mean Square Residual) $=0.048$ (<0.05 very good). According to these results, the model demonstrated a very good fitness and the construct validity of the 5-dimensions with 23-items scale was proven.

\section{Item Statistics and Reliability Values}

The level of difficulty of items ranged between 3.10 and 3.69 for the dimension 'Interaction Confidence', 3.57 and 3.69 for 'Interaction Awareness'; 4.24 and 4.32 for 'Respect of Cultural Difference', 3.42 and 3.78 for 'Difficulty in Interaction' and 3.85 and 4.02 for 'Interaction Enjoyment'(Table 3). According to the discrimination values, the total value of items in each dimension were positive and above 0.40 , which suggests that the items have a good degree of discrimination [25]. The items exemplify similar behaviors and have high levels of internal consistency. (Scale's items were presented in Supplemental Material.)

Table 3. Item Statistics and Reliability Values 


\begin{tabular}{|c|c|c|c|c|c|}
\hline & Difficulty & $\begin{array}{l}\text { Discrimination Values } \\
\text { (Point Biserial } \\
\text { Correlation) }\end{array}$ & $\begin{array}{l}\text { Cronbach's Alpha } \\
\text { (when item } \\
\text { deleted) }\end{array}$ & $\begin{array}{l}\text { Cronbach's } \\
\text { Alpha }\end{array}$ & $\begin{array}{l}\text { Spearman-Brown } \\
\text { Coefficient }\end{array}$ \\
\hline \multicolumn{6}{|c|}{ Interaction Confidence } \\
\hline Item 1 & 3.69 & 0.671 & 0.819 & 0.851 & 0.869 \\
\hline Item 2 & 3.59 & 0.609 & 0.837 & & \\
\hline Item 3 & 3.10 & 0.654 & 0.824 & & \\
\hline Item 4 & 3.27 & 0.714 & 0.807 & & \\
\hline Item 24 & 3.45 & 0.676 & 0.817 & & \\
\hline \multicolumn{6}{|c|}{ Interaction Awareness } \\
\hline Item 11 & 3.57 & 0.645 & 0.650 & 0.772 & 0.706 \\
\hline Item 13 & 3.69 & 0.657 & 0.637 & & \\
\hline Item 15 & 3.59 & 0.524 & 0.780 & & \\
\hline \multicolumn{6}{|c|}{$\begin{array}{l}\text { Respect of Cultural } \\
\text { Difference }\end{array}$} \\
\hline Item 17 & 4.24 & 0.613 & 0.840 & 0.848 & 0.802 \\
\hline Item 18 & 4.32 & 0.752 & 0.779 & & \\
\hline Item 19 & 4.25 & 0.723 & 0.791 & & \\
\hline Item 20 & 4.31 & 0.663 & 0.816 & & \\
\hline \multicolumn{6}{|c|}{ Difficulty in Interaction } \\
\hline Item 22 & 3.50 & 0.617 & 0.793 & 0.826 & 0.819 \\
\hline Item 23 & 3.78 & 0.636 & 0.789 & & \\
\hline Item 25 & 3.42 & 0.520 & 0.813 & & \\
\hline Item 30 & 3.52 & 0.656 & 0.785 & & \\
\hline Item 36 & 3.45 & 0.559 & 0.805 & & \\
\hline Item 38 & 3.54 & 0.578 & 0.802 & & \\
\hline \multicolumn{6}{|c|}{ Interaction Enjoyment } \\
\hline Item 26 & 3.86 & 0.561 & 0.797 & 0.817 & 0.801 \\
\hline Item 33 & 3.85 & 0.530 & 0.803 & & \\
\hline Item 40 & 4.02 & 0.647 & 0.772 & & \\
\hline Item 41 & 3.86 & 0.621 & 0.778 & & \\
\hline Item 42 & 3.96 & 0.693 & 0.755 & & \\
\hline \multicolumn{6}{|c|}{ For all items of the scale } \\
\hline Cronbach's Alpha & 0.906 & & & & \\
\hline $\begin{array}{l}\text { Spearman-Brown } \\
\text { Coefficient }\end{array}$ & 0.779 & & & & \\
\hline
\end{tabular}

Cronbach's alpha values were 0.851 for 'Interaction Confidence', 0.772 for 'Interaction Awareness', 0.848 for 'Respect of Cultural Difference', 0.826 for 'Difficulty in Interaction' and 0.817 for 'Interaction Enjoyment', and 0.906 for the total score. These values suggested that the scale has a high level of reliability [26]. The Spearman-Brown coefficients for the whole scale and the dimensions show that the scale's split-half reliability values were also sufficient.

\section{Intercultural Sensitivity Status of the Medical Students}


The mean total score of students was $85.84 \pm 11.44$, which shows a good level of intercultural sensitivity. (Table 4). However, there are some outliers (1\% got 23 points).

Table 4. Dispersion Statistics of Total and Sub-Dimension Scores of the Students (Hacettepe Univ.-Ankara, 2017)

\begin{tabular}{|c|c|c|c|c|}
\hline Scale and Sub-Dimensions & Median & $1^{\text {st_-3 }}{ }^{\text {rd }}$ Quarter & Min-Max & \\
\hline Interaction Confidence & $17.10 \pm 3.67$ & 17.00 & $15.00-20.00$ & $5.00-25.00$ \\
\hline Interaction Awareness & $10.86 \pm 1.94$ & 11.00 & $9.00-12.00$ & $3.00-15.00$ \\
\hline Respect of Cultural Differences & $17.12 \pm 2.70$ & 18.00 & $16.00-20.00$ & $4.00-20.00$ \\
\hline Difficulty in Interaction & $21.21 \pm 4.22$ & 21.00 & $18.00-24.00$ & $6.00-30.00$ \\
\hline Interaction Enjoyment & $19.55 \pm 3.00$ & 20.00 & $18.00-21.00$ & $5.00-25.00$ \\
\hline TOTAL & $85.84 \pm 11.44$ & 86.00 & $79.00-93.00$ & $23.00-115.00$ \\
\hline
\end{tabular}

The scores of female students were significantly higher than males on 'Respect of Cultural Differences' and 'Interaction Enjoyment' dimensions (Mann-Whitney U test; $p=0.002$ and $p=0.001$, respectively)

Students who have neighbors from different cultures have significantly higher scores on the sub-dimensions of 'Interaction Confidence', 'Difficulty in Interaction' and 'Interaction Enjoyment'(Mann-Whitney U test; $p=0.003, p=0.036$, respectively, $p<0.001$ ). Students who have the chance to interact with people from different cultures had higher scores on the sub-dimensions of 'Interaction Confidence', 'Interaction Awareness' 'Difficulty in Interaction' and 'Interaction Enjoyment' (Mann-Whitney U test; $p<0,001, p=0.001, p<0.001, p<0.001$, respectively). The students who examine patients from different cultures had significantly higher scores on the sub-dimensions of 'Interaction Confidence' $(\mathrm{p}<0.001)$, 'Interaction Awareness' $(\mathrm{p}=0.004)$ and 'Difficulty in Interaction' ( $\mathrm{p}=0.046)$ (Mann-Whitney U test) (Table 5).

\section{Discussion}

The Cronbach's alpha value of the scale was found as 0.906, which was higher than Chen and Starosta's value (0.86) [27] for Communication students. In two other studies from Turkey, Bulduk et al. found as 0.72 [28] among nursing students and Üstün found as 0.90 [29] among teacher candidates in 2011. Different cultures and languages in the surveyed communities, and differences of profession and the education received in communities with similar culture might cause this variation.

As a result of factor analyses, the items of 'Interaction Confidence' dimension of the original scale [23] were loaded to the same dimension in our study except Item 34 which replaced with Item 24. Similarly, 'Respect of Cultural Difference' dimension loaded with the same items as in the original one except items 6 and 14. Original 'Interaction Enjoyment'dimension was totally differed from the original scale and five different items were loaded to this dimension (items 26, 33, 40, 41, 42). The items loaded 'Interaction Engagement' and 'Interaction Attentiveness' dimensions of the original scale were totally changed related to the analysis, and two new dimensions were defined namely 'Interaction Awareness' and 'Difficulty in Interaction' considering the content of the items (Figure 2).

In the study conducted by Bekiroğlu and Balcı among Communication Faculty students by using the original scale of Chen and Starosta [23], 5 sub-dimensions did not repeat completely, and 4 sub-dimensions could be handled similar to the current study; the authors thought that this difference could have sourced from the cultural differences among the studied groups [30].

The findings of Bekiroğlu and Balcı's study support the analysis of current study. Since the attitudes of the American society against the individuals from other cultures, where the original scale was developed differ from Turkish youth (and medical students in particular), it is an expectable result. These findings also point out that direct application of the scales which evaluate the social characteristics of the societies is not appropriate without conducting the proper adaption studies.

In the study conducted by Meydanlıoğlu et al among medical and nursery students, male students had significantly higher scores than female students for 'Interaction Enjoyment' and 'Interaction Confidence' dimensions [18] while the scores of female students were significantly higher than males on 'Respect of Cultural Differences' and 'Interaction Enjoyment' dimensions in the current study. However, no significant difference was found in Bekiroğlu and Balcı's and Üstün's studies related to intercultural sensitivity scores by sex [29,30]. The study of Bekiroğlu and Balcı also suggests that the levels of intercultural sensitivity increases as the frequency of interacting with people from different cultures [30] as well as the current study. The study of Üstün also suggests that the respondents with friends from different cultures have significantly higher intercultural sensitivity scores [29]. 
Many studies demonstrate racial/ethnic inequalities in healthcare services. For this reason, movement towards cultural competences in healthcare services has become nationally important, and is recognized by health policy makers, health administrators, academicians, service providers and beneficiaries as a strategy for addressing racial/ethnic inequalities in health and healthcare services [31]. 'Healthy People 2020', a strategic plan for public health, defines one of its four basic goals as 'reducing inequalities in healthcare services and providing culturally competent care as key instruments of enhancing health justice'. Culturally competent and sensitive healthcare improve the trust, satisfaction and adherence of patients and play a key role in raising the heath literacy of patients [32].

Culturally competent health services provision is needed to reduce inequalities in health. Addressing these inequalities and improving health justice trough training programs on this subject have become one of the key goals of both educational institutions and public health organizations.

Betancourt et al's study supports cultural competence training at all levels of education including "before and during Faculty of Medicine education as well as continuous medical education". Graduate Medical Education Accreditation Committee has emphasized the important role played by Faculties of Medicine in addressing inequalities in the field of health, and underscored the need for medical teachers to evaluate the cultural competences of students. A "culturally competent" has been defined as a system that acknowledges and incorporates, at all levels, the importance of culture, assessment of cross-cultural relations, vigilance toward the dynamics that result from cultural differences [31]. Some studies evaluating the effectiveness of cultural competence training on physicians and medical students have demonstrated that such training had positive results in increasing intercultural sensitivity [33,34].

\section{Conclusion}

The adapted form of 23-item and 5-dimension 'Intercultural Sensitivity Scale' is a valid and reliable instrument, which could be used for Turkish medical students by the teaching staff of medical faculties. Under the light of findings of this study, it is considered that integrating intercultural sensitivity training in the curriculum of medical education would help to gain medical students' cognitive, affective, psycho-motor domains on intercultural sensitivity. It is recommended to test the validity and reliability of this adopted scale on other medical faculty students.

\section{Practice Points}

- It is important to evaluate perception of medical students related to intercultural sensitivity considering their future profession.

- The adapted form of 23-item and 5-dimension 'Intercultural Sensitivity Scale' is a valid and reliable instrument, which could be used for Turkish medical students by the teaching staff of medical faculties.

\section{Declarations}

\section{Ethics declarations}

Ethics approval and consent to participate

Permission from the Dean's Office of the Faculty of Medicine of Hacettepe University, and Hacettepe University Non-Interventional Clinical Researches Ethics Board's approval were obtained as well as participants' informed consents. This study has been conducted with the guidance of ethical approval. Participation of the study was voluntary basis; participants remained anonymous. The permission was taken to perform this adaptation study from Prof. Guo-Ming Chen.

\section{Consent for publication}

Consent was given by all authors.

Availability of data and materials

The data sets generated and/or analyzed during the current study are not publicly available for now since this study comprises one part of a comprehensive project and other stages are not yet completed, but are available from the corresponding author on reasonable request.

\section{Competing interests}

The authors report no conflict of interest.

Funding 
This study is funded through the UK Research and Innovation GCRF RESEARCH FOR HEALTH IN CONFLICT (R4HC-MENA); developing capability, partnerships and research in the Middle and Near East (MENA) ES/P010962/1.

\section{Authors' contributions}

Planning and design of the study and interpretation of the results: Şevkat Bahar-Özvarış, Bahar Güçiz-Doğan

Data collection and entry: Tuğçe M. Şanver, Çağla Susuz

Data analysis and interpretation: Hande Konşuk-Ünlü

Writing the manuscript: Şevkat Bahar-Özvarış, Bahar Güçiz-Doğan, Hande Konşuk-Ünlü, Tuğçe M. Şanver, Çağla Susuz, Richard Sullivan

\section{Acknowledgments}

The authors thank UK Research and Innovation GCRF RESEARCH FOR HEALTH IN CONFLICT (R4HC-MENA) for supporting this research. Also, the authors thank Prof. Guo-Ming Chen for permission to use the Intercultural Sensitivity Scale.

\section{References}

1. Ministry of Interior Directorate General of Migration Management. Up-to-date Statistics Entrance and Exit. https://en.goc.gov.tr/entry--exit. Accessed 8 Feb 2021.

2. United Nations, International Migration Report 2017. https://www.un.org/en/development/desa/population/migration/publications/migrationreport/docs/MigrationReport2017_Highlights.pdf. Accessed 8 Feb 2021.

3. United Nations High Commissioner for Refugees (UNHCR), Statistics. https://www.unhcr.org/tr/unhcr-turkiye-istatistikleri. Accessed 8 Feb 2021.

4. Ministry of Interior Directorate General of Migration Management. Up-to-date Statistics Syrian Refugees Under Temporary Protection. https://en.goc.gov.tr/temporary-protection27. Accessed 8 Feb 2021.

5. UNHCR Turkey Key Facts and Figures. http://www.unhcr.org/tr/unhcr-turkiye-istatistikleri. Accessed 8 Feb 2021.

6. Ministry of Interior Directorate General of Migration Management (DGMM). Residence Permits. https://en.goc.gov.tr/residence-permits. Accessed 8 Feb 2021.

7. Ministry of Interior Directorate General of Migration Management (DGMM). Irregular Immigration. https://en.goc.gov.tr/irregular-migration. Accessed 8 Feb 2021.

8. Arslan N, Çakı N. Uluslararası göçün bireyin sağlığı üzerindeki etkisi ve Türkiye'de sunulan sağlık hizmetlerine ilişkin bir inceleme. Sosyal Bilimler. 2017;15:101.

9. Koçan S, Demirci Güngördü N, Demir A, Üstün Ç. Bir grup sağlık çalışanının bakış açısıyla göçmen sorunu: Nitel bir çalışma. Electronic Turkish Studies. 2017;12(31):361-378.

10. Alkan A, Erdem R, Çelik R. Sağlık alanındaki ayrımcı tutum ve davranışlar kavramsal bir inceleme. Hacettepe Sağlık İdaresi Dergisi. 2016;19(3):365-390

11. Demir E, Ergin I, Kurt A, Etiler N. Present state, problems and obstacles encountered in the use of health services by refugees/people under temporary protection. War, Migration and Health: Experience of Turkey. Ankara: Turkish Medical Association Publications. 2016. p.6068. https://www.ttb.org.tr/kutuphane/siginmacilar_rpr_en.pdf. Accessed 8 Feb 2021.

12. Önal A, Keklik B. Mülteci ve Sığınmacıların Sağlık Hizmetlerine Erişiminde Yaşadığı Sorunlar: Isparta Illinde Bir Uygulama. Süleyman Demirel Üniversitesi Vizyoner Dergisi. 2016;7(15):132-148.

13. Perng SJ, Watson R. Construct validation of the Nurse Cultural Competence Scale: a hierarchy of abilities. Journal of Clinical Nursing. 2012;21(11-12):1678-1684

14. Betancourt JR. Cross-cultural medical education: conceptual approaches and frameworks for evaluation. Academic Medicine. 2003;78(6):560-569.

15. Derose KP, Escarce JJ, Lurie N. Immigrants and health care: sources of vulnerability. Health Affairs. 2007;26(5):1258-1268.

16. Asgary R, Segar N. Barriers to health care access among refugee asylum seekers. Journal of Health Care for the Poor and Underserved. 2011;22(2):506-522.

17. Fernandez A, Schillinger D, Grumbach K, Rosenthal A, Stewart AL, Wang F, Pérez-Stable EJ. Physician Language Ability and Cultural Competence. Journal of General Internal Medicine. 2004;19(2):167-174. 
18. Meydanlioglu A, Arikan F, Gozum S. Cultural sensitivity levels of university students receiving education in health disciplines. Advances in Health Sciences Education. 2015;20(5):1195-1204.

19. Cruz JP, Alquwez N, Cruz CP, Felicilda-Reynaldo RFD, Vitorino LM, Islam SMS. Cultural competence among nursing students in Saudi Arabia: a cross-sectional study. International Nursing Review. 2017;64(2):215-223.

20. Sherrill WW, Mayo RM, Truong KD, Pribonic AP, Schalkoff CA. Assessing medical student cultural competence: what really matters. Int J Med Educ. 2016;7:248-254.

21. Lanting K, Dogra N, Hendrickx K, Nathan Y, Sim J, Suurmond J. "Culturally Component in Medical Education-European Medical Teachers" Self-Reported Preparedness and Training Needs to Teach Cultural Competence Topics and to Teach a Diverse Class'. MedEdPublish. 2019;8(2):28.

22. Green AR, Chun MB, Cervantes MC, Nudel JD, Krupat E, Betancourt JR. Measuring medical students' preparedness and skills to provide cross-cultural care. Health equity. 2017;1(1):15-22.

23. Chen GM, Starosta WJ. The development and validation of the Intercultural Sensitivity Scale. Human Communication. 2000;3(1):2-14.

24. Kaiser HF. An index of factorial simplicity. Pyschometrika. 1974;39(1): 31-36.

25. Büyüköztürk Ş. Sosyal Bilimler İçin Veri Analizi El Kitabı. 15 ${ }^{\text {th }}$ Ankara: Pegem Akademi; 2011. p. 124-130, 170.

26. Tavşancıl E. Tutumların Ölçülmesi ve SPSS ile Veri Analizi. 5th ed. Ankara: Nobel Akademik Yayıncılık Eğitim Danışmanlık Tic. Ltd. Şti; 2014. p. 29, 33, 50-51.

27. Cruz JP, Estacio JC, Bagtang CE, Colet C. Predictors of cultural competence among nursing students in the Philippines. Nurse Education Today. 2016;46:121-126.

28. Bulduk S, Tosun H, Ardıç E. Türkçe kültürler arası duyarlılık ölçeğinin hemşirelik öğrencilerinde ölçümsel özellikleri. Turkiye Klinikleri Journal of Medical Ethics-Law and History. 2011;19(1):25-31.

29. Üstün E. 2011. Öğretmen Adaylarının Kültürlerarası Duyarlılık ve Etnikmerkezcilik Düzeylerini Etkileyen Etmenler [master's thesis]. Yıldız Teknik University.

30. Bekiroğlu O, Balcı Ş. Kültürlerarası iletişim duyarlılığının izlerini aramak: "iletişim fakültesi öğrencileri örneğinde bir araştırma”. Selçuk Üniversitesi Türkiyat Araştırmaları Dergisi. 2014;1(35):429-459.

31. Betancourt JR, Green AR, Carrillo JE, Owusu Ananeh-Firempong II. Defining cultural competence: a practical framework for addressing racial/ethnic disparities in health and health care. Public Health Reports. 2016;118(4):293-302.

32. Horky S, Andreola J, Black E, Lossius M. Evaluation of a cross cultural curriculum: changing knowledge, attitudes and skills in pediatric residents. Maternal and Child Health Journal. 2017;21(7):1537-1543.

33. Palmer RC, Samson R, Triantis M, Mullan ID. Development and evaluation of a web-based breast cancer cultural competency course for primary healthcare providers. BMC Medical Education. 2011;11(1):59.

34. Staton LJ, Estrada C, Panda M, Ortiz D, Roddy D. A multimethod approach for cross-cultural training in an internal medicine residency program. Medical Education Online. 2013;18(1):20352.

\section{Table 5}

Table 5. Sub-Dimension Scores of Respondents by Some of Their Characteristics (Hacettepe University - Ankara, 2017) 


\begin{tabular}{|c|c|c|c|c|c|c|c|}
\hline \multirow[t]{4}{*}{ racteristics } & \multicolumn{7}{|c|}{ Sub-Dimensions of Inter-Cultural Sensitivity Scale } \\
\hline & \multirow{3}{*}{$\begin{array}{l}\text { Interaction } \\
\text { Confidence } \\
\text { Median (Min-Max) }\end{array}$} & \multirow{3}{*}{$\begin{array}{l}\text { Interaction } \\
\text { Awareness } \\
\text { Median (Min-Max) }\end{array}$} & \multirow{3}{*}{$\begin{array}{l}\text { Respect of Cultural } \\
\text { Differences } \\
\text { Median (Min-Max) }\end{array}$} & \multirow{3}{*}{$\begin{array}{l}\text { Difficulty in } \\
\text { Interaction } \\
\text { Median (Min-Max) }\end{array}$} & \multirow{2}{*}{$\begin{array}{l}\text { Interaction } \\
\text { Enjoyment }\end{array}$} & \multirow{3}{*}{$\begin{array}{l}\text { TOTAL } \\
\text { Median } \\
\text { Max) }\end{array}$} & \multirow{3}{*}{ (Min- } \\
\hline & & & & & & & \\
\hline & & & & & Median (Min-Max) & & \\
\hline \multicolumn{8}{|l|}{$\mathrm{n}$} \\
\hline $\mathrm{V}$ & $17.00(5.00-25.00)$ & $11.00(3.00-15.00)$ & $18.00(4.00-20.00)$ & $21.00(6.00-30.00)$ & $20.00(5.00-25.00)$ & 86.00 & $(23.00-$ \\
\hline \multicolumn{2}{|l|}{$(\mathrm{n}=404)$} & & & & & 115.00) & \\
\hline l & $17.00(9.00-25.00)$ & $11.00(4.00-15.00)$ & $17.00(5.00-20.00)$ & $21.00(9.00-30.00)$ & $20.00(6.00-25.00)$ & 86.00 & $(47.00-$ \\
\hline \multicolumn{2}{|l|}{$(n=263)$} & & & & & 115.00) & \\
\hline lue* & 0.151 & 0.294 & 0.350 & 0.754 & 0.750 & 0.368 & \\
\hline \multicolumn{8}{|l|}{ der } \\
\hline ale $\quad(n=$ & $17.00(6.00-25.00)$ & $11.00(3.00-15.00)$ & $18.00(6.00-20.00)$ & $21.00(9.00-30.00)$ & $20.00(6.00-25.00)$ & 86.00 & $(47.00-$ \\
\hline \multicolumn{2}{|l|}{ 351) } & & & & & 115.00) & \\
\hline$(\mathrm{n}=316)$ & $17.00(5.00-25.00)$ & $11.00(3.00-15.00)$ & $17.00(4.00-20.00)$ & $21.50(6.00-30.00)$ & $20.00(5.00-25.00)$ & $\begin{array}{l}86.00 \\
115.00)\end{array}$ & $(23.00-$ \\
\hline \multirow{2}{*}{\multicolumn{8}{|c|}{$\begin{array}{l}\text { ue* } \\
\text { nd from different culture }\end{array}$}} \\
\hline & & & & & & & \\
\hline$(n=13)$ & $17.00(11.00-25.00)$ & $10.00(7.00-15.00)$ & $18.00(10.00-20.00)$ & $21.00(16.00-29.00)$ & $\begin{array}{l}21.00 \\
25.00)\end{array}$ & $\begin{array}{l}88.00 \\
111.00)\end{array}$ & $(67.00-$ \\
\hline $\mathrm{n}=278)$ & $17.00(5.00-25.00)$ & $11.00(3.00-15.00)$ & $17.50(4.00-20.00)$ & $21.00(6.00-30.00)$ & $20.00(5.00-25.00)$ & $\begin{array}{l}84.50 \\
115.00)\end{array}$ & $(23.00-$ \\
\hline \multirow{2}{*}{$\begin{array}{l}\text { ue* } \\
\text { rhbor from o } \\
(n=433)\end{array}$} & $\begin{array}{l}0.367 \\
\text { ifferent cultures }\end{array}$ & 0.818 & 0.794 & 0.459 & 0.151 & 0.337 & \\
\hline & $18.00(6.00-25.00)$ & $11.00(3.00-15.00)$ & $18.00(5.00-20.00)$ & $22.00(10.00-30.00)$ & $20.00(6.00-25.00)$ & $\begin{array}{l}87.00 \\
115.00)\end{array}$ & $(47.00-$ \\
\hline $\mathrm{n}=159)$ & $16.00(5.00-25.00)$ & $11.00(3.00-15.00)$ & $17.00(4.00-20.00)$ & $21.00(7.00-30.00)$ & $20.00(8.00-25.00)$ & $\begin{array}{l}84.00 \\
115.00)\end{array}$ & $(52.00-$ \\
\hline \multirow{3}{*}{$\begin{array}{l}\text { lue* } \\
\text { action with } \\
(n=585)\end{array}$} & 0.003 & 0.092 & 0.092 & 0.036 & $<0.001$ & $<0.001$ & \\
\hline & different cultures & & & & & & \\
\hline & $17.00(5.00-25.00)$ & $11.00(3.00-15.00)$ & $18.00(4.00-20.00)$ & $22.00(6.00-30.00)$ & $20.00(5.00-25.00)$ & $\begin{array}{l}86.00 \\
115.00)\end{array}$ & (23.00- \\
\hline $\mathrm{n}=82)$ & $15.00(5.00-24.00)$ & $10.00(3.00-15.00)$ & $17.50(5.00-20.00)$ & $19.50(8.00-30.00)$ & $19.00(8.00-25.00)$ & $\begin{array}{l}80.00 \\
110.00)\end{array}$ & (53.00- \\
\hline \multirow{3}{*}{$\begin{array}{l}\text { ue* } \\
\text { nining patie } \\
(n=431)\end{array}$} & $<0.001$ & 0.001 & 0.505 & $<0.001$ & $<0.001$ & $<0.001$ & \\
\hline & its from different cult & ures & & & & & \\
\hline & $18.00(5.00-25.00)$ & $11.00(3.00-15.00)$ & $17.00(4.00-20.00)$ & $22.00(6.00-30.00)$ & $20.00(5.00-25.00)$ & $\begin{array}{l}86.00 \\
115.00)\end{array}$ & $(23.00-$ \\
\hline $\mathrm{n}=234)$ & $16.00(5.00-25.00)$ & $11.00(3.00-15.00)$ & $18.00(5.00-20.00)$ & $21.00(9.00-30.00)$ & $20.00(6.00-25.00)$ & $\begin{array}{l}84.00 \\
115.00)\end{array}$ & $(50.00-$ \\
\hline ue* & $<0.001$ & 0.004 & 0.358 & 0.046 & 0.128 & 0.004 & \\
\hline
\end{tabular}

rd the term 'intercultural sensitivity' 


\begin{tabular}{|c|c|c|c|c|c|c|c|}
\hline$(n=200)$ & $19.00(9.00-25.00)$ & $12.00(4.00-15.00)$ & $18.00(4.00-20.00)$ & $23.00(12.00-30.00)$ & $20.00(6.00-25.00)$ & 91.00 & $(47.00-$ \\
\hline \multirow{3}{*}{$\mathrm{n}=449)$} & \multirow{3}{*}{$16.00(5.00-25.00)$} & \multirow{3}{*}{$11.00(3.00-15.00)$} & \multirow{3}{*}{$17.00(4.00-20.00)$} & \multirow{3}{*}{$21.00(6.00-30.00)$} & \multirow{3}{*}{$20.00(5.00-25.00)$} & 115.00) & \multirow{3}{*}{ (23.00- } \\
\hline & & & & & & 84.00 & \\
\hline & & & & & & 115.00) & \\
\hline lue* & $<0.001$ & 0.001 & 0.125 & $<0.001$ & $<0.001$ & $<0.001$ & \\
\hline
\end{tabular}

* Mann-Whitney U test

Figures

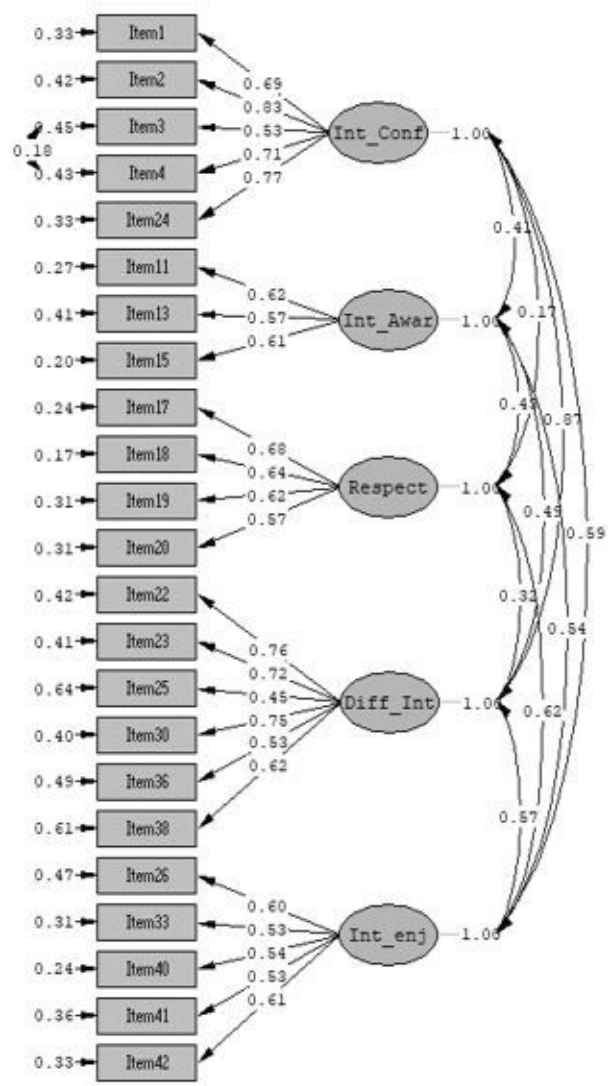

Chi-Square $=649.27, d f=219, \mathrm{P}-\mathrm{value}=0.00000, \mathrm{RMSEA}=0.077$

\section{Figure 1}

Path Diagram Obtained from CFA 

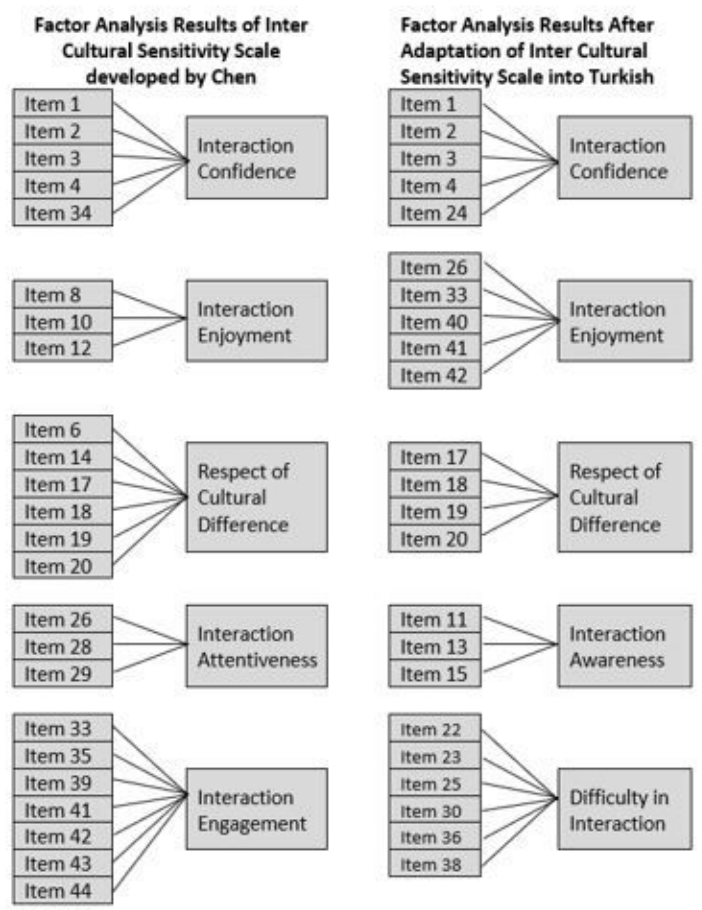

\section{Figure 2}

Changes in item loadings on dimensions before and after factor analysis

\section{Supplementary Files}

This is a list of supplementary files associated with this preprint. Click to download.

- SupplementaryMaterialed.docx 